URL: http://ojs.unimal.ac.id/index.php/ekonomi_regional

\title{
PENGARUH PDRB DAN PENGELUARAN PEMERINTAH PROVINSI PAPUA TERHADAP KEMISKINAN DI PAPUA
}

\author{
Marlina ${ }^{* a}$, Umaruddin Usman ${ }^{*} \mathrm{~b}$ \\ *Fakultas Ekonomi dan Bisnis Universitas Malikussaleh \\ a Corresponding author:wmarlina@gmail.com \\ b umaruddin@unmal.ac.id
}

\begin{tabular}{l} 
A R T I C L E I N F O R M A T I O N \\
\hline Keywords: \\
GRDP, Government Expenditure \\
and Poverty
\end{tabular}

A B S T R A C T

The purpose of this study was to see the effect of GRDP and Expenditure on the Provincial Government of Papua on Poverty in Papua. The data used in this study are secondary data sourced from the Central Statistics Agency (BPS). The data analysis method used in this study is multiple linear regression with the help of the program package eviews 10. The results showed that the GRDP variable has a negative effect on poverty, while the government expenditure variable does not negatively affect poverty, but together the GRDP variable and Government expenditure positively influences poverty in Papua and the magnitude of the effect of GRDP variable and government expenditure on poverty is 0.6966 (69.66\%). Recommendations, it is expected that the local government of Papua can increase the GRDP which will be able to minimize poverty in Papua.

\section{PENDAHULUAN}

Provinsi papua salah satu provinsi yang memiliki kekayaan sumber daya alam yang cukup maksimal dalam bidang sektro pertambangan. Perekonomian provinsi Papua saat ini 50\% dibantu oleh sektor pertambangan tersebut. 2,5 miliar ton didalamnya yaitu batuan biji emas dan tembaga yang dapat membantu ekonomi daerah tersebu, semuanya terdapat di wilayah konsesi Freport. Provinsi Papua memiliki SDA terbanyak sesuaipenjelasansebelumnyaseharusnya dapat membantu melancarkankegiatanekonomi di provinsi tersebut, namun berbeda dengan kenyataan yang ada, bahwasanya provinsi papua menjadi provinsi yang paling belakang dan terbanyak angka tingkat kemiskinan di Indonesia. Hal tersbut karena dapat dilihat angka kemiskinan pada tahun 2019. Penduduk miskin di provinsi Papua yakni mencapai $27,74 \%$ dari populasi. Indonesia ada kurang lebih 74 ribu desa/wilayah. Diantara desa/wilayah tersebut $18 \%$ atau 18.126 desa/wilayahtermasuk wilayah tertinggal, yang besar di kawasan Indonesia timur. Ketertinggal tersebut membuat angka kemiskinan di daerahdaerah tersebut tinggi (BPS Indonesia, 2018).

Angka PDRB di Provinsi Papua mengalami naik turun atau terjadi secara fluktuatif selama 8 tahun bahwa selama 3 tahun dari tahun 2010 sampai 2012 terjadipengurangan dan kembali meningkat 5 tahun sebelumnya PDRB papua terus mengalami peningkatakan kembali, hal ini dikarenakan pemerintah Pusat telah berkontribusi tentang perusahaan Free port terbesar di provinsi Papua bahwa hasil pembagian batu bara yang dilakukan harus dibagia sama rata, atau cenderung provinsi papua atau Indonesia harus lebih banyak memperoleh keuntangan.

Kemudian untuk pengeluaran pemerintah bahwa angka pengeluaran di provinsi papua selalu meningkat selama 8 tahun terakhir, pengeluaran pemerintah di provinsi selama 8 tahun terkahir ini meningkat dikarenakan pemerintah sudah berkontribusi untuk membangun kesejahteraan dengan membangun infrasturktur-infrastuktur di provinsi Papua dan serta pembangunan di daerah pelosok. Dengan adanya pengeluaran pemerintah yang dilakukan dengan signifikan maka kemiskinan di provinsi selama 8 tahun tersebut menurundengancukupbaik.

Penelitian ini didukung oleh penelitian yang dilakukan bahwa (Ratih, 2017) dengan judul pengaruh investasi, pengeluaran pemerintah, tenaga kerja dan PDRB terhadap tingkat kemiskinan pada wilayah Sarbagita di Provinsi Bali bahwa semua variabel yang diteliti memiliki pengaruh terhadap tingkat kemiskinan. 
Penelitian ini juga didukung dengan penelitian yang dilakukan oleh (Amalia, 2015) dengan judul pengaruh pengeluaran pemerintah terhadap kemiskinan di provinsi Sulawesi bahwa pengeluaran pemerintah memiliki pengaruh terhadap kemiskanan.

Kemudian penelitian yang dilakukan oleh (Dama, 2016) dengan judul pengaruh PDRB terhadap tingkat kemiskinan di Kota Manado bahwa PDRB memiliki pengaruh terhadap tingkat kemiskinan.

Untuk melihat perkembangan dan fenomena yang terjadi pada angka PDRB, Pengeluaran Pemerintah dan Kemiskinandi Provinsi selama kurun waktu 8 tahun di Provinsi Papua sebagai berikut:

\section{Tabel 1}

Angka PDRB,

Pengeluaran Pemerintah dan Kemiskinan

\begin{tabular}{|c|c|c|c|}
\hline Tahun & $\begin{array}{c}\text { PDRB } \\
\text { Di Provinsi } \\
\text { Papua } \\
\text { (Rp) }\end{array}$ & $\begin{array}{c}\text { Pengeluaran } \\
\text { Pemerintah } \\
\text { Di Provinsi } \\
\text { Papua } \\
\text { (Rp) }\end{array}$ & $\begin{array}{c}\text { Kemiskinan } \\
\text { Di Provinsi } \\
\text { Papua } \\
(\%)\end{array}$ \\
\hline 2010 & 110.808 .000 .000 & 5.803 .839 .000 & 34,01 \\
\hline 2011 & 106.066 .000 .000 & 7.183 .484 .000 & 34,11 \\
\hline 2012 & 107.890 .000 .000 & 8.241 .636 .000 & 30,66 \\
\hline 2013 & 117.118 .000 .000 & 8.209 .736 .000 & 31,52 \\
\hline 2014 & 121.391 .233 .000 & 11.315 .078 .000 & 27,80 \\
\hline 2015 & 130.311 .604 .000 & 12.986 .632 .000 & 28,17 \\
\hline 2016 & 142.221 .091 .000 & 13.071 .335 .000 & 28,54 \\
\hline 2017 & 148.823 .629 .000 & 15.158 .877 .000 & 27,62 \\
\hline
\end{tabular}

Sumber: Badan Pusat Statistik (2018)

Dari tabel 1 diatas dapat kita lihat data selama 8 tahun dari tahun 2010-2017 di provinsi Papua ada berbagai variasi dan dan terjadi secara fluktuatif. Masalah yang timbul pada angka (PDRB) yaitu ditahun 2012 dan 2013, dimana pada tahun 2013 angka (PDRB) sebesar Rp 117.118.000.000 meningkat dari tahun sebelumnya yaitu pada tahun 2012 angka PDRB sebesar Rp 107.890.000.000, namun peningkatan pada tahun 2013 timbulnya masalah pada angka kemiskinan yang meningkat, pada tahun 2012 angka kemiskinan mencapai $30,66 \%$ dan pada tahun 2013 meningkat menjadi 31,52\%, sehingga timbullah masalah pada tahun-tahun tersebut yang tidak sesuai dengan teori yang ada, dimana teori menyebutkan bahwa ketika PDRB meningkat maka akan menurunkan angka kemiskinan(Mahsunah, 2013).

Pada tabel diatas angka yang jadi permasalahan ketika PDRB meningkat namun kemiskinan makin meningkat dikarenakan PDRB meningkat disebabkan karena sumber daya yang dimiliki di provinsi Papua sangat baik dan melimpah, namun hasil penggunaan sumber daya tersebut tidak digunakan sepenuhnya oleh masyarakat provinsi papua karena ada pembagianpembagian khusus yang dilakukan oleh pusat untuk penghasilan yang diperoleh (Mahsunah, 2013).

Selanjutnya masalah yang timbul dari pengeluaran pemerintah adalah ketika pengeluaran pemerintah meningkat angka kemiskinan juga ikut meningkat. Dari tahun 2010-2017 angka pengeluaran pemerintah selalu meningkat tiap tahunnya, namun untuk angka kemiskinan terjadi penurunan dan peningkatan di tahun-tahun tertentu. Dapat kita lihat pada tabel diatas bahwa terjadi permasalahan antara pengeluaran pemerintah dengan kemiskinan timbul pada tahun 2010-2011 yaitu angka pengeluaran pemerintah tahun 2010 sebesar Rp 5.803.839.000 meningkat tahun 2011 menjadi Rp 7.183.484.000 namun angka kemiskinan juga meningkat dari tahunm sebelumnya $34,01 \%$ menjadi $34,11 \%$. Sehingga timbullah masalah pada tahun-tahun tersebut yang tidak sesuai dengan teori yang ada, dimana teori menyebutkan bahwa ketika pengeluaran pemerintah meningkat maka akan menurunkan angka kemiskinan (Mahsunah, 2013).

Tujuan yang ingin dicapai padapenelitian untuk mengetahui pengaruh PDRB dan Pengeluaran Pemerintah Provinsi Papua terhadap Kemiskinan di Provinsi Papua.

\section{KAJIAN TEORITIS}

\section{PDRB}

PDRB adalah nilai bersih barang dan jasajasa alkhir yang dihasilkan oleh berbagai kegiatan ekonomi disuatu daerah dalam periode. (Sukirno, 2004).

Berdasarkan teori diatas maka dapat disimpulkan PDRB (Produk Domestik Regional Bruto) merupakan nilai tambah yang dihasilkan dari produksi suatu negara dapat dihitung berdasarkan harga berlaku dan harga konstan.

Hubungan antara variabel PDRB memiliki hubungan negatif terhadap kemiskinan, dimana ketika angka PDRBmeningkat maka akan menurunkan kemiskinan, karena ketika angka pemasukan akan lebih besar biasanya akan membantu mengurangi angka kemiskinan yang akan dibagi rata kesetiap masyarakat(Mahsunah, 2013). 
Menurut penelitian (Mahsunah, 2013) PDRB adalah penambahannilai persektor dbaik dilihat dari harga konstan maupun harga berlaku.

Menurut penelitian (Dama, 2016) PDRB adalah nilai akhir barang dan jasa dihitung berdasarkan pesektor disuatu wilayah.

Kemudian penelitian dari(Permana, 2012) PDRB merupakan seluruh nilai akhir yang dihasilkan dari sektor ekonomi disuatu wilayah.

\section{Pengeluaran Pemerintah}

Pengeluaran

pemerintah merupakansalahsatuidndikatordarikebijakan fiscal, untukmengaturjalannyapemerintahbaikdalambentu kpengeluaranmaupunpenerimaandihitungadariang grana APBN. (Sitaniapessy, 2013).

Pengeluaran pemerintah merupakan alokasi anggaran yang disusun dalam APBN atau APBD. (Subri, 2013)

Berdasarkan pakar diatas maka dapat diambil kesimpulan pengeluaran poemerintah adalahbiaya-biaya yang dikeluarkan pada pihak pemerintahan untuk kebutuhan masyarakat demi mensejahterakan masyarakat.

Hubungan antara pengeluaran pemerintah memiliki hubungan negatif terhadap kemiskinan, dimana ketika pengeluaran pemerintah semakin tinggi maka akan mengurangikemiskinan, karena pengeluaran pemerintah diperlukanpada beberapa belanja diantaranya belanja konsumsi untuk masyarakat yang akan mampu meningkatkan kapasitas kehidupan seperti belanja padabebeerapasektor dan pemberian subsidi sehingga masyarakat sedikit tertolong dengan adanya pengeluaran pemerintah seperti hal tersebu maka akan mampu memerangi angka kemiskinan (Fithri, 2017).

\section{Kemiskinan}

Kemiskinan adalah gambaran kekurangan materi, kebutuhan sosial termasuk keterkucilan sosial, ketergantungan maupun ketidakmampuan untuk berpartisipasi pada masyarakat dan gambaran tentang kurangnya penghasilan dan kekayaan yang memadai (Ellah, 2016).

Kemiskinan adalah keadaanseseroangtidakmampumemenuhikebutuha nhidupnya(Bapennas, 2004).

Kemiskinan merupakan ketertinggalan dan penghambat dalam perekonimian suatu negara dalah tingginya angka kemiskinan (Aswandi, Hairul, \& Kuncoro, 2002).
Berdasarkan teori para pakar diatas dapat kemiskinan merupakan kondisi seseorang atau sekelompok orang yang tidak dapat memenuhi kebutuhannya yang akan dapat menghambat pertumbuhan ekonomi dan merupakan masalah pemerintah yang harus dihadapi dan dituntaskan.

Menurut penelitian (Permana, 2012) kemiskinan adalah ketidakmampuan masyarakat dalam memenuhi kebutuhan diri dan keluarganya.

Menurut penelitian yang dilakukan oleh (Mahsunah, 2013) kemiskinan adalah tidak ada dayanya masyarakat dalam memenuhi kebutuhan sehari-hari.

Menurut penelitian yang dilakukan oleh (Suryawati, 2005) kemiskinan adalah salah faktor ekonomi yang akan menghambat pertumbuhan ekonomi akibat tidak adanya kesejahteraan hidup masyarakat didalamnya.

\section{Kerangka Konseptual}

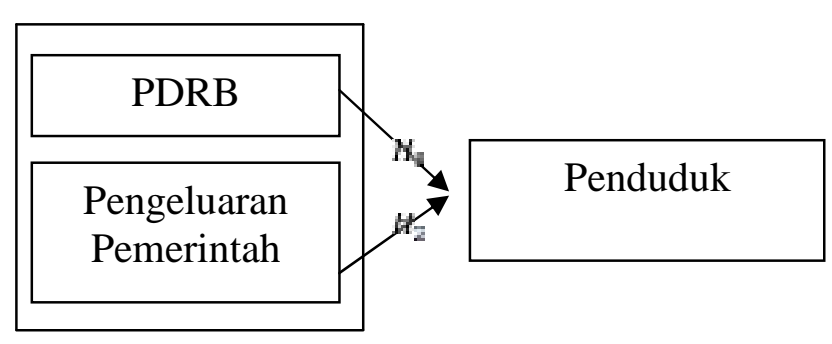

\section{Gambar 1 Kerangka Konseptual}

\section{Hipotesis}

Berdasarkan kerangka konseptual diatas maka dapat diambil hipotesis sebagai berikut:

$H_{1} \quad$ : PDRB berpengaruh terhadap Kemiskinan di Provinsi Papua

$\mathrm{H}_{2} \quad$ : Pengeluaran Pemerintah berpengaruh terhadap Kemiskinan di Provinsi Papua

\section{METODE PENELITIAN}

\section{Data dan Sumber Data}

Data yang digunakan adalah data sekunder yang diperoleh melalui publikasidata yang dikeluarkan oleh BPSIndonesia selama 15 tahun dari tahun 2002-2017. 


\section{Definisi Operasional Variabel}

a. PDRB $\left(X_{1}\right)$ : PDRB (Produk Domestik Regional Bruto) merupakan nilai tambah yang dihasilkan dari produksi suatu negara dapat dihitung berdasarkan harga berlaku dan harga konstan. Skalaukuran yang digunakandalam Rupiah.

b. Pengeluaran Pemerintah $\left(X_{2}\right)$ :suatu kegiatan pemerintahan sehari-hari untuk proses meningkatkan kesejahteraan masyarakat. Skalaukuran yang digunakandalamRupiah.

c. Kemiskinan (Y):Kondisi dimana seseorang atau sekelompok orang tidak mampu memenuhi hak-hak dasarnya untuk mempertahankan dan mengembangkan kehidupan yang bermartabat. Skalaukuran yang digunakandalamPersen (\%).

\section{Metode Analisis data}

Untuk memecahkan masalah pada penelitian ini maka penulis melakukan analisis data dengan memakai metode kuantitatif dengan menggunakan alat statistik yaitu programEviews versi 10 yang berupa metode Regresi Linier Berganda (RLB) sebagai berikut:

$$
\log \mathrm{Y}=\beta_{\mathrm{0}}+\beta_{1} L \quad{ }_{1}+\beta_{2} L \quad X_{2}+\mathrm{ei}
$$

Dimana: $\log \mathrm{Y}=$ Kemiskinan

$$
\begin{array}{cl}
\beta_{0}=\text { Konstanta } & \\
\beta_{1} & =\text { Koefisien regresi } \\
\log X_{1} & =\text { PDRB } \\
\log X_{2} & =\text { Pengeluaran Pemerintah } \\
\text { ei } \quad \text { Error Term }
\end{array}
$$

\section{Uji Normalitas}

Uji normalitas dihitung untuk mengetahu hasil penelitian terdistribusi normal atau tidak. Pengujian normalitas dapat dilakukan dengan menggunakan metode Jarque-Bera (J-B). Jika nilai probability dari statistik J-B lebih besar dari taraf kepercayaan $5 \%(0,05)$ berarti bahwa residul data berdistribusi normal begitupun sebalinya (Widarjono, 2013).

\section{Uji Asumsi Klasik}

Adapun uji asumsi klasik yang digunakan dalam penelitian ini adalah sebagai berikut:

\section{Uji Multikolinearitas}

Uji multikolinearitas dilakukan untuk melihat apakah anar variabel ada saling berhubungan atau mempengaruhi(Subri, 2013).

$\mathrm{R}^{2} / \mathrm{k}$ adalah koefisien determinasi $\left(\mathrm{R}^{2}\right)$ berganda ketika $X_{k}$ diregresikan dengan variabelvariabel X lainnya. Batas Tolerance Value adalah 0,01 dan batas VIF adalah 10 .

Dimana :

Tolerancevalue $<0,01$ atau VIF $>10$ terjadi multikolinearitas

Tolerance value $>0,01$ atau VIF $<10$ tidak terjadi multikolinearitas

\section{Uji Autokorelasi}

Tesautokorelasiinidimaksudkanuntukmengid entifikasiapakahadakorelasiantarkeadaanvariabelg angguan(disturbance)padaperiodetertentudenganv ariabelgangguan(disturbance)padaperiode lain. (Subri, 2013). Pendeteksianterhadappenyimpanganasumsiklasiku ntukatuokorelasidapatdilihatpadabesarnyanilaiBre usch-Godfrey Test. JikanilaiObs. $R$ Squaredtidaksignifikanmaka data tidakterjadiautokorelasi.

\section{Pengujian Hipotesis}

Uji t

Uji t dilakukan untuk melihat apakah ada hubungan antara variabel bebas dan variabel terikat secara parsial (Subri, 2013). Adapun kriteria pengujiannya adalah sebagai berikut:

1. Jika $t_{\text {nit }}>t_{t_{1}} \quad$ Ho ditolak dan menerima Ha yang artinya variabel bebas (X) secara parsial mempengaruhi variabel terikat $(\mathrm{Y})$.

2. 2. Jika $t_{\text {nii }}<t_{t_{i}}$ maka Ho diterima dan menolak Ha yang artinya variabel bebas (X) secara parsial tidak mempengaruhi vaiabel terikat $(\mathrm{Y})$.

\section{Uji F}

Uji Fdilakukan untuk pengaruh secara simultan variabel bebas terhadap variabel terikat. Apabila uji $\mathrm{F}$ hitung lebih besar dari nilai $\mathrm{F}$ tabel maka variabel independen secara keseluruhan berpengaruh terhadap variabel dependen (Gujarati, 2004). Adapun kriteria pengujian yang digunakan sebagai berikut:

1. Jika $F_{\text {nit }}>F_{t_{1}}$ maka Ho ditolak dan menerima $\mathrm{Ha}$ yang artinya variabel bebas 
(X) secara simultan atau serentak berpengaruh signifikan variabel terikat $(\mathrm{Y})$

2. Jika $F_{\text {nit }} \quad<F_{\tau_{1}}$ maka Ho diterima dan menolak Ha yang artinya variabel bebas $(\mathrm{X})$ secara simultan atau serentak tidak berpengaruh signifikan variabel terikat $(\mathrm{Y})$.

\section{Koefisien Korelasi (R)}

Menurut (Sugiyono, 2015)Koefisien korelasi (R) merupakan gambaran untuk melihat pengaruh keseluruhan variabel yang dapat kia bandingkan dengan penelitian lain.

Pedoman untuk memberikan interpretasi koefisien sebagai berikut (Sugiyono, 2013):

$$
\begin{aligned}
& \text { - >0,00 - 0,199 = sangat rendah } \\
& \text { - }>0,20-0,399=\text { rendah } \\
& \text { - }>0,40-0,599=\text { sedang } \\
& \text { - }>0,60-0,799=\text { kuat } \\
& \text { - }>0,80-0,99=\text { sangat kuat } \\
& \text { - }>1=\text { korelasi sempurna }
\end{aligned}
$$

\section{Koefisien Determinasi $\left(\boldsymbol{K}^{Z}\right)$}

Koefisien determinasi $\left(R^{2}\right)$ adalah satu ukuran yang digunakan untuk mengukur pengaruh variabel independen terhadap variansi dependen, dengan $0<K^{2}<1$. Koefisien determinasi pada regresi linier sering diartikan sebagai seberapa besar kemampuan semua variabel bebas dalam menjelaskan varians dari variabel terikatnya. (Subri, 2013).

\section{HASIL PENELITIAN DAN PEMBAHASAN}

\section{HasilRegresi Linier Berganda}

Untuk melihat hasil estimasi model penelitian data yang diolah dengan bantuan program Eviews versi 10 maka diperoleh hasil perhitungan analisis regresi seperti yang ditunjukkan pada gambar berikut ini:

Tabel 2

\section{Hasil Analisis Regresi Linear Berganda}

\begin{tabular}{lrlr}
\multicolumn{1}{c}{ Variable } & Coefficient & t-Statistic & Prob. \\
\hline \hline C & 154.9435 & 6.537208 & 0.0000 \\
LOG(PDRB) & -4.839351 & -2.455238 & 0.0303 \\
LOG(P_P) & -0.035208 & -0.014061 & 0.9890 \\
\hline \hline \multirow{2}{*}{ R-squared } & 0.739998 & F-statistic & 17.07678 \\
Adjusted R-squared & 0.696665 & Prob(F-statistic) & 0.000309 \\
& & Durbin-Watson stat & 1.533442 \\
\hline \hline
\end{tabular}

Sumber: HasilPenelitian, 2019 (data diolah)

$$
Y=154.9453-4.839351 L \quad X_{1}-0.0 \quad L \quad X_{z}
$$

Nilai konstanta sebesar 154.9453 artinya jika variabel PDRBdanPengeluaran Pemerintahbernilai nol, maka variabeldependen Kemiskinansebesar $154.9453 \%$.

Nilai koefisien regresi PDRB sebesar 4.839351 menunjukkan hubungan negatif yang memberiartijikavariabelPDRBmeningkatsebesar 1\% makaakanmenurunkan variable Kemiskinansebesar4.839351\%.

Nilai koefisien Pengeluaran pemerintah sebesar -0.035208 menunjukkan hubungan negatifyang memberi arti bahwa jikavariabelpengeluaran pemerintah meningkat meningkatsebesar

$1 \%$ makaakanmenurunkanvariabelkemiskinansebes ar0.035208\%.

\section{Uji Normalitas}

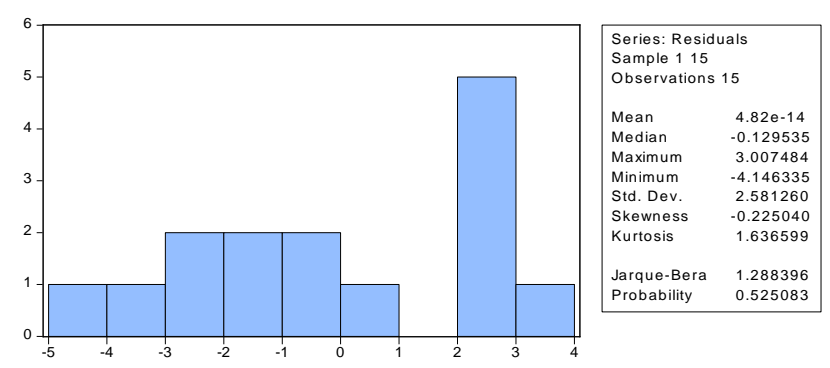

Sumber: HasilPenelitian, 2019 (data diolah)

\section{Gambar 2 Uji Normalitas}

Nilai $X^{2}(C-S \quad)$ tabel dengan $\operatorname{df}(2)$ $=$ 5,99. Jikadibandingkandengannilai J-B padatabel4.4sebesar1.28<5,99,

makadapatdisimpulkanbahwa model regresi, variabelpengganguatau residual dalam model sudahterdistribusidengan normal. Hal inijugabisadilihatdariprobabilitas (P-value) sebesar $0,52>0,05$.

\section{Hasil Uji Asumsi Klasik Hasil Uji Multikolonieritas}

\begin{tabular}{cccc} 
Variance Inflation Factors & & \\
Variable & $\begin{array}{c}\text { Coefficient } \\
\text { Variance }\end{array}$ & $\begin{array}{c}\text { Uncentered } \\
\text { VIF }\end{array}$ & $\begin{array}{c}\text { Centered } \\
\text { VIF }\end{array}$ \\
\hline \hline C & 561.7746 & 1084.035 & NA \\
LOG(PDRB) & 3.884964 & 4536.651 & 5.607237 \\
LOG(PP) & 6.269895 & 6027.089 & 5.607237 \\
\hline \hline
\end{tabular}

Sumber: HasilPenelitian, 2019 (data diolah)

Tabel 3

\section{UjiMultikolinieritas}

Variance Inflation Factors 
Halinibermaknabahwasemakintinggiangka PDRB $\left(X_{1}\right)$, makaakan menurunkan Kemiskinandi provinsi Papua. Hal tersebut dikarenakan angka PDRB yang disalurkan di provinsi Papua dapat digunakan semaksimal mungkin dengan baik sehingga dengan disalurkan angka PDRB tersebut mampu mempengaruhi dengan menurunkan angka kemiskinan di provinsi tersebut.

Hasilpenelitianinisejalandenganpenelitian yang dilakukanoleh(Dama, 2016)di Kota Manado, PDRBberpengaruhnegatifterhadapKemiskinan di Kota Manadodengannilaisignifikanpada $u=5 \%$. Inimenunjukkanbahwa di Kota Manado semakintinggi PDRB akan menurunkan angka Kemiskinan di Kota Manado.

Kemudian penelitian yang dilakukan oleh (Permana, 2012) di Jawa Tengah bahwa PDRBberpengaruhnegatifterhadapKemiskinan di Jawa tengah. Inimenunjukkanbahwa di Kota Manado semakintinggi PDRB akan menurunkan angka Kemiskinan di Jawa Tengah.

\section{PengaruhPengeluaran}

\section{PemerintahTerhadapKemiskinan}

Berdasarkanhasilanalisis data

ditemukanbahwavariabelpengeluaran pemerintah $\left(X_{2}\right)$ tidak berpengaruhterhadapvariabelKemiskinan dansignifikansebesar $u=$ $5 \%$.

Hal inibermaknabahwajikapengeluaran pemerintah $\left(X_{2}\right) \quad$ meningkat Rupiah, makatidak akanmenurunkankemiskinan di provinsi Papua. Hal ini dikarenakan bahwa setiap pengeluaran pemerintah di Provinsi Papua tidak semua dikeluarkan untuk masyarakat namun ada sebagian yang dilakukan untuk kepentingan pemerintahan seperti belanja pegawai, belanja barang untuk kepentingan pemerintahan (Suparmoko, 2005).

Hasilpenelitianinisejalandenganpenelitian yang dilakukanolehDama (2016) di Kota Manado, pengeluaran pemerintahtidak berpengaruhnegatifterhadapKemiskinan di Kota Manadodengannilaisignifikanpada $u=5 \%$.

Inimenunjukkanbahwa di Kota Manado semakintinggi pengeluaran pemerintah tidak akan menurunkan angka Kemiskinan di Kota Manado.

Kemudian penelitian yang dilakukan oleh (Amalia, 2015) di Sulawesi Barat bahwa pengeluaran

pemerintahberpengaruhnegatifterhadapKemiskina $\mathrm{n}$ di Sulawesi Barat.

Kemudian penelitian yang dilakukan oleh (Fithri, 2017) di Jawa Timur bahwa pengeluaran pemerintah berpengaruh secara negatif terhadao kemiskinan yang artinya apabilan pengeluaran pemerintah meningkah maka akan mengurangi angka kemiskinan di Jawa Timur.

\section{PENUTUP}

\section{Kesimpulan}

1. Hasil yang ditemukanvariabelPDRBberpengaruhsecaran egatifterhadapKemiskinan di Provinsi Papua.

2. VariabelPengeluaran Pemerintah tidakberpengaruhsecaranegatifterhadapKemi skinan di Provinsi Papua artinyasemakintinggi angka pengeluaran pemerintah maka juga tidak akan menurunkan kemiskinan di Provinsi Papua.

3. SecarabersamasamavariabelPDRBdanPengeluaran PemerintahberpengaruhpositifterhadapKemi skinan di Provinsi Papua, danbesarnyaPDRBdanPengeluaran PemerintahterhadapKemiskinanadalahsebesa r69.66\% dansisanyasebesar $(1-69,66 \%)=$ $30,34 \%$ dapatdijelaskandiluar model penelitianini.

\section{Saran}

Adapun beberapa saran-saran yang diharapkan penulis dalam penelitian ini adalah sebagai berikut:

1. Dengan adanya perbedaan teori ini dapat menambah wawasan kepada peneliti untuk memperluasa wawasan dengan mencari jalan tentang kemiskinan yang diperoleh bahwa kemiskinan tidak hanya dipengaruhi oleh faktor di dalam penelitian ini, bahwasanya kemiskinan juga dipengaruhi oleh faktorfaktor didalam penentu kemiskinan seperti kesehatan dan pendidikan.

2. Diharapkankepada pemerintahdaerah dan pemerintah pusat agar dapat membantu dan mendorong kegiatan pertumbuhan ekonomi di provinsi Papua, dengan memperhatikan variabel-variabel penting seperti peneliti lakukan yaitu variabel PDRB, Pengeluaran Pemerintah dan kemiskinan yang salah satu menjadi tolak ukur bagi pembangunan ekonomi di provinsi Papua.

3. Perluadanyapenelitianlanjutan, sehinggadiperolehtemuan yang lebihbervariasidanlebihbaikdalammenjelaskan variabel Kemiskinan denganmetodepenelitian yang berbeda. 


\section{DAFTAR PUSTAKA}

Amalia. (2015). Pengaruh Pengeluaran Pemerintah Terhadap Kemiskinan di Provinsi Sulawesi Barat. Jurnal Analisis, Vol 4 No.2.

Aswandi, Hairul, \& Kuncoro, M. (2002). Evaluasi Penetapan Kawasan Andalan: Studi Empiris di Kalimantan Selatan 1993-1999. Jurnal Ekonomi Dan Bisnis Indonesia, vol 11, 7589.

Bapennas. (2004). Statistik Perhubungan. Buku KeII Perpustakaan Bappenas.

Dama. (2016). Pengaruh Produk Domestik Regional Bruto (PDRB) Terhadap Tingkat Kemiskinan di Kota Manado (Tahun 20052014). Jurnal Berkala Ilmiah Efesiensi, Vol 16 No.

Ellah. (n.d.). Analisis Pertumbuhan Sektor Utama terhadap Tingkat Kemiskinan, Tingkat Pengangguran, dan Indeks Pembangunan Manusia (IPM) di Satuan Wilayah Pembangunan Madiun dan Sekitarnya 20032013. Jurnal Ilmiah.

Fithri, N. dan D. K. (2017). Analisis Pengaruh Pengeluaran Pemerintah Sektor Pendidikan dan Kesehatan Terhadap Kemiskinan di Jawa Timur. Jurnal Ekonomi Pembangunan, Vol 15 No.

Indra Van, W. (2013). Analisis Pengaruh PDRB, Pendidikan dan Pengangguran Terhadap Kemiskinan di Provinsi Jawa Tengah Tahun 2005-2010.

Laporan Perekonomian Indonesia LPI 2016. (n.d.). Bank Indonesia.

Mahsunah. (2013). Analisis Faktor-Faktor yang Mempengaruhi Tingkat Kemiskinan Nasional di Indonesia Tahun 2005-2009. Jurnal Ekonomi Pembangunan, Vol 8 No.

Permana. (2012). Analisis Pengaruh Pdrb, Pengangguran, Pendidikan, Dan Kesehatan Terhadap Kemiskinan Di Jawa Tengah Tahun 2004-2009. Dipenogoro Journal If Economics, Vol 1 No.

Ratih, G. A. (2017). Pengaruh Investasi, Pengeluaran Pemerintah, Tenaga Kerja Terhadap Produk Domestik Regional Bruto dan Tingkat Kemiskinan pada Wilayah Sarbagita di Provinsi Bali. E-Jurnal Ekonomi Dan Bisnis Universitas Udayan, Vol 6 No.

Sitaniapessy. (2013). Pengaruh Pengeluaran Pemerintah Terhadap PDRB dan PAD. Jurnal Economica, Vol 9 No.

Subri. (2013). Ekonomi Sumber Daya Manusia. (P. R. G. Persada, Ed.). Jakarta.

Sugiyono. (2015). Statistik Untuk Penelitian.
Bandung: Alfabeta.

Sukirno, S. (2003). Ekonomi Pembangunan. Jakarta: PT. Raja Grafindo Persada.

Sukirno, S. (2004). Pengantar Teori Makro. Jakarta: PT. Graha Grafindo.

Suryawati. (2005). Memahami Kemiskianan Multidimensional. Jurnal Pelayanan

Kesehatan, Vol. 8 No.

Widarjono, A. (2013). Ekonometrika. Yogyakarta: Edisi Keempat. 